\title{
Leto 1968 v Cerkvi v Sloveniji in Vekoslav Grmič
}

\author{
Year 1968 in the Church of Slovenia \\ and Vekoslav Grmič
}

Povzetek: Leto 1968 je bilo ob vseh svojih vseevropskih razsežnostih pomembno tudi za mariborsko škofijo. Delna obnova visokošolskega študija teologije v obdravskem mestu je sovpadla s škofovskim posvečenjem Vekoslava Grmiča. Svojevrstno "pomlad" teološke misli v Mariboru in na Slovenskem je omogočil preplet različnih notranjecerkvenih in zunanjih okoliščin, ki pa je sočasno začrtal tudi njene meje. Med njimi je treba omeniti predvsem splošno navdušenje nad drugim vatikanskim cerkvenim zborom in "vzhodno politiko« papeža Pavla VI. Vekoslav Grmič je bil še posebej primeren za nosilno figuro teh teženj, saj ni bil le nosilec tedaj sodobnih teoloških pogledov, marveč je bil kot pripadnik »vzhodnoštajerskega toka" v slovenski katoliški skupnosti sočasno vsebinsko blizu nekaterim postulatom komunističnih oblasti na Slovenskem. Toda nepripravljenost slednjih na kakorkoli enakopravno obravnavo Cerkve in zaostritev izhodiščnih postavk »vzhodnoštajerskega toka« katoliške misli v Grmičevem krogu sta sčasoma povečali razkorak med tem krogom in večino slovenskih katoličanov ter pripeljali do zatona »Grmičevega desetletja« po letu 1978.

Ključne besede: Vekoslav Grmič, teologija na Štajerskem v 20. stoletju, „vzhodna politika«, Pavel VI., Cerkev v komunizmu

\begin{abstract}
The year 1968 was not only a pivotal year in contemporary European history, but also important for the Maribor diocese. A partial reestablishment of higher education studies in theology in Maribor coincided with Vekoslav Grmičs elevation to the post of auxiliary bishop. The "spring" of theological thought in Maribor and Slovenia was enabled by the interweaving of various internal and external circumstances, which simultaneously outlined its boundaries. Among them, one should mention the general enthusiasm caused by the Second Vatican Council and the "Ostpolitik" of Pope Paul VI. Vekoslav Grmič was especially suitable as a frontrunner of such aspirations, since he was not only a champion of contemporary theological views then, but as a representative of the "Eastern Styrian current "inside the Slovene Catholic community he also shared some basic ideas of the Communist authorities in Slovenia. However, the fundamental unwillingness of these authorities to treat Church as an equal partner in any way and the radicalization of some already problematic concepts of the "Eastern Styrian current of the Catholic thought in the Grmic circle eventually widened the gap between this circle and a sizeable part of the Slovene Catholics and led to the decline of the "Grmič decade" after 1978.
\end{abstract}

Key words: Vekoslav Grmič, theology in Styria in 20th century, „Ostpolitik«, Paul VI., Church under Communism 


\section{Uvod}

Leto 1968 je bilo ob vseh svojih vseevropskih razsežnostih pomembno tudi za razmeroma sveže preimenovano lavantinsko škofijo. Vsaj delna obnova visokošolskega študija teologije v obdravskem mestu je pri tem sovpadla s škofovskim posvečenjem ene njenih gonilnih sil, mladega profesorja dogmatike Vekoslava Grmiča. Ker je mož isto leto prevzel še predsedovanje Mohorjevi družbi, lahko prav z njim označimo začetek obdobja njegovega največjega vpliva v Cerkvi na Slovenskem. Kot sem na nekem mestu že naredil (Maver 2013, 604), si bom tudi tukaj drznil deset let med 1968 in 1978 krstiti kar za »Grmičevo desetletje». Čeprav je šlo z vidika zgodovine slovenske katoliške skupnosti za kratek časovni odsek, sem mnenja, da je pomembno zaznamoval razvoj v njej tako rekoč do danes. Zato je v povezavi z obeleževanjem petih desetletij mariborske enote ljubljanske Teološke fakultete umestno osvetliti tudi kulturnozgodovinske okoliščine njene vzpostavitve, zlasti v povezavi z osebnostjo Vekoslava Grmiča.

Svojevrstno "pomlad « teološke misli v Mariboru in na Slovenskem v drugi polovici šestdesetih in $\mathrm{v}$ prvi polovici sedemdesetih let prejšnjega stoletja je omogočil preplet različnih notranjecerkvenih in zunanjih okoliščin, ki pa je sočasno začrtal tudi njene meje. Med komponentami tega prepleta velja na prvem mestu omeniti drugi vatikanski cerkveni zbor, ki je s svojimi reformami sprožil val navdušenja in optimizma ter po svoje integrativno deloval na slovenske katoličane, za katere izkušnja druge svetovne vojne in povojne popolne komunistične prevlade ni bila samo travmatična, temveč je sočasno okrepila že prej navzoče močne delitve med njimi. Toda pozna šestdeseta leta so bila v socialistični slovenski republiki in še ponekod drugod po Jugoslaviji tudi čas t. i. partijskega »liberalizma« (Repe 1992), pri čemer je seveda narekovaj premalo, da bi poudaril zasilnost tega pojma $v$ razmerah enopartijskega sistema povojnega obdobja. In kot je treba s previdnostjo rabiti besedo liberalizem v tej zvezi, je imela tudi kratkotrajna »liberalizacija «v razmerju do katoliške skupnosti zelo omejen, kot bomo videli, morda celo dvoumen domet. Tretji pomemben dejavnik je bil vzpon »vzhodne politike« papeža Pavla VI., ki je podobno kot večina koncilskih očetov na drugem vatikanskem cerkvenem zboru izhajala iz predpostavke, da bo komunistični projekt pod sovjetsko egido še dolgo obvladoval dobršen del srednje in vzhodne Evrope, zato se je skušalo cerkveno vodstvo prilagoditi novim, za bolj ali manj trajne pripoznanim 
razmeram. O rezultatih tega obrata, ki se je začel nakazovati že pod Janezom XXIII., so bila mnenja tedaj in so še danes deljena. Vsekakor pa je »vzhodna politika«znotraj posameznih krajevnih Cerkva spodbujala teološko-politični razvoj, kakršen je bil v »Grmičevem desetletju« značilen za Cerkev na Slovenskem. Na jugoslovanskem območju je »vzhodna politika" poleg tega prinesla otoplitev odnosov med Titovo državo in vrhom vesoljne Cerkve, kar je prav tako treba upoštevati pri presojanju dogajanja na Slovenskem. Kot zadnjo komponento mešanice, iz katere je vstala »teološka pomlad«s konca šestdesetih let, navajam dejstvo, da je »štajerski« ali morda še bolje »vzhodnoštajerski« tok v slovenskem katolištvu, ki je predstavljal v predvojnih razmerah manjšinsko ali celo na rob potiskano usmeritev, v prvih povojnih desetletjih prišel v ospredje in postal vsaj tista smer, ki je tako rekoč edina vsaj nekoliko lahko prišla v javnost. Tu je bil pomožni škof Grmič znova njen bistveni glasnik.

\section{Katoliška cerkev na Slovenskem pred letom 1968}

Kot že rečeno, je pomenila druga svetovna vojna s svojim epilogom - popolno prevlado zmagovite komunistične strani $\mathrm{v}$ javnem življenju - odločilno zarezo v zgodovini slovenskega katolištva. Vendar ni mogoče zanemariti še drugih dejavnikov, ki so sooblikovali njegov težavni položaj v dvajsetih letih po tej prelomnici. Drugačno kot v nekaterih sicer primerljivih okoljih (Kerševan 1989, 53-54) je bilo že razmerje med katoliško vero in oblikovanjem posebne slovenske narodne zavesti, čeprav zaradi tega samoumevnost pripadnosti katoliški veri vsaj od protireformacijskih časov ni bila nič manj izrazita. Toda katoliški monolit je začenjal po vsem videzu razpoke dobivati že vsaj v začetku 20. stoletja. Eden pomembnih vzvodov tega procesa je bilo pretirano povezovanje pripadnosti katolištvu s pripadnostjo katoliški stranki. ${ }^{1}$ Doslej po mojem mnenju ne dovolj upoštevan dejavnik je bil tudi katolištvu nenaklonjeni državni okvir že po prvi svetovni vojni, ki je ustvaril ugodne okoliščine za močnejši prodor nekaterih po drugi svetovni vojni bistveno bolj izraženih laicističnih zamisli (Košir 2002, 260 sl.; Dolinar 2007, 242-244; Kolar 2014, 375-376; Maver

1 Značilna so denimo tozadevna, v začetku štiridesetih let 20. stoletja zapisana mnenja ljubljanskega generalnega vikarja Ignacija Nadraha (Nadrah 2010, 170-175; Ambrožič 2011, 604). 
2014b, 506-508). Lahko bi celo rekli, da so slovenski katoličani prestopili iz enega modela razmerja med državno skupnostjo in katolištvom v drugega. Zanj je bilo značilno, da so katoličani, podobno kot denimo v Nemčiji, na Nizozemskem ali v Švici, predstavljali pomembno manjšino prebivalstva, a so bili v javnem življenju soočeni s številnimi trdovratnimi klišeji (Maver in Friš 2018; Altermatt 2007). Stvari je znatno zaostril dokaj izrazit razkol v katoliški skupnosti sami v drugi polovici tridesetih let 20. stoletja (Pirc 1997), ki ni mogel pozitivno vplivati na odzivanje Katoliške cerkve kot gotovo najmočnejše posamične organizacije na Slovenskem na katastrofalno preizkušnjo okupacije (Maver 2014a, 57-58; Kolar 2014). Nemogoče je zanikati, da so v ozračju pravega državljanskega spopada na velikem delu slovenskega ozemlja ugled Cerkve v javnosti oslabile nekatere sporne odločitve med samo vojno. Medvojno in povojno komunistično nasilje pa je pospešilo še bistveno kadrovsko ošibitev, katere pomen je komaj mogoče ceniti previsoko (Griesser Pečar 2005; Griesser Pečar 2016; Bizilj 1991, 94-95). To je vplivalo na razmere še v šestdesetih in sedemdesetih letih 20. stoletja.

Naslednja okoliščina je bila, da je bila Cerkev za po drugi svetovni vojni na Slovenskem vladajoče strukture benignejši nasprotnik kot ponekod drugod v tistih delih Evrope, ki so jih obvladovali komunistični režimi. Če je šlo višje na severu in vzhodu vendarle predvsem za slabo zakrito obliko sovjetske okupacije, so imeli slovenski komunisti spričo samostojnega prevzema oblasti boljše izhodišče, cerkvena hierarhija pa slabše. Pri ocenjevanju njenega položaja se torej ne kaže ustavljati pri oceni oblasti, po kateri je katoliška skupnost vseskozi predstavljala pomembnega nasprotnika, zaradi česar ji je posvečala nadpovprečno pozornost (Bizilj 1991; Griesser Pečar 2016).

Po letu 1945 se je ne glede na razlike, ki sem jih nakazal, glavnina srednje- in vzhodnoevropskih katoličanov, ne le slovenskih in jugoslovanskih, znašla pod prevlado že v izhodišču sovražnih komunističnih režimov, toda njihov položaj se je od države do države precej razlikoval. Ni veliko dvomov, da se jim je daleč najslabše godilo v Albaniji in takoj zatem v Sovjetski zvezi (Solchanyk in Hvat 1990). In če je Albanija uradno prepovedala vsakršno versko prepričanje, so bile zunaj nje take radikalne obravnave ponekod deležne grškokatoliške skupnosti (Malmenvall 2014; 2016; Solchanyk in Hvat 1990, 74 sl.). 
Pri presojanju položaja drugih katoliških skupnosti ni enega kriterija, po katerem bi bilo mogoče razvrstiti države zunaj omenjenih Sovjetske zveze in Albanije. S stališča Svetega sedeža, ki je najprej stavil na normalno delujočo redno cerkveno hierarhijo, so bile visoko pred vsemi deželami Poljska, Socialistična federativna republika Jugoslavija (oziroma v veliki meri že Federativna ljudska republika Jugoslavija) in Madžarska. V to skupino je vsaj po letu 1972 spadala tudi Nemška DR, kjer pa je bilo katoličanov zunaj eichsfeldske enklave v Turingiji in nekaterih lužiškosrbskih območij na Saškem le malo (Goeckel, 1990). Kar zadeva samo vidik diplomatskih stikov s Svetim sedežem, je bila SFRJ prva, ki jih je v celoti normalizirala (Stehle, 1990, 345; Kolar 2018). Vendar je šlo pri zunanjem okviru, ki je bil nedvomno pomemben, zgolj za en vidik življenja katoliških skupnosti. Zdi se, da tega zagovorniki »vzhodne politike« Pavla VI. niso mogli nikoli zares razumeti. V Jugoslaviji (in nemara še posebej v Sloveniji, kot kažejo denimo zgledi pri Dolinar 2006) je šlo namreč tudi za okolje, kjer so oblasti ob Sovjetski zvezi in seveda Albaniji vložile največ truda v omejevanje javne navzočnosti katoliške ter pravzaprav vsakršne religioznosti. Omenjeno se je med drugim kazalo v doslednem izgonu verskih praznikov iz uradnega koledarja, ki drugod v srednji Evropi skoraj ni imel ustreznice in ga je le slabo prikrivalo sklicevanje na versko pestrost jugoslovanske države (Kerševan, 1989, 131; Casaroli 2001, 350). Dober pokazatelj v temelju sovražnega odnosa jugoslovanskega in še prav posebej slovenskega režima do vsake, zlasti pa katoliške religioznosti je tudi sorazmerno dosledno prečiščevanje jezika. Oblasti se namreč niso ustavile zgolj ob temeljitem prekrščevanju krajev s pretirano po krščanski dediščini zaudarjajočimi imeni (z glavnim valom sredi petdesetih let, ko je, recimo, celo Nova Cerkev morala postati Strmec) - pred posegi za »versko nevtralnost« besedil vnetih niso bile varne niti Andersenove pravljice (Bizilj 1991; Lodrant 1979).

Kot olajševalno okoliščino je mogoče navesti, da je bil jugoslovanskim katoličanom prihranjen pojav podtalne mreže duhovnikov in večjega razkola med v režimska društva včlanjenimi duhovniki in vsemi preostalimi, kar je močno zaznamovalo predvsem Cerkvi na Češkoslovaškem in Madžarskem (Kolar 2008; Reban 1990, 145 sl.). Razkorak med člani Cirilmetodijskega in poznejšega Slovenskega duhovniškega društva in drugimi je na Slovenskem sicer obstajal, a je ostal brez najbolj dramatičnih posledic (Griesser Pečar 2017; Griesser Pečar 2002, 296-297; Rosa 2003; Čipić Rehar 2007). 
Kot ob številnih drugih vprašanjih slovenske stvarnosti po drugi svetovni vojni je treba, tudi ko razmišljamo o položaju Katoliške cerkve, upoštevati širši okvir skupne (jugoslovanske) države. Povedano je bilo, da je bila njena verska pestrost pogosto uporabljana kot priročen izgovor za omejevanje izražanja verskih prepričanj v javnosti. Smernice verske politike so bile pri tem po državi v osnovi enotne, a kot je v podrobnostih obstajala razlika v obravnavi posameznih verskih skupnosti zaradi njihovih posebnosti, so obstajale razlike v položaju katoliške skupnosti v različnih zveznih enotah. V štirih med njimi (Slovenija, Hrvaška, Bosna in Hercegovina in Vojvodina) so bili katoličani vsaj številčno sila, s katero je bilo treba računati (čemur bi bilo mogoče dodati še v okvir Cerkve na Hrvaškem vključeno črnogorsko Boko Kotorsko).

Hitre primerjave se hitro vrnejo kot bumerang, vendar že bežen pregled institucionalnih možnosti zgolj na področju verskega tiska in šolstva pokaže, da sta Slovenija in Bosna in Hercegovina tozadevno (precej) zaostajali za Hrvaško (Griesser Pečar 2016 in Akmadža 2013). Če je bilo katoličanom v Bosni in Hercegovini že zaradi manjšinskega položaja znotraj zvezne enote še posebno težko (Lučić 2012), je bil pritisk oblasti na Slovenskem vsaj v nekaterih valovih komaj kaj manjši (Dolinar 2006; Bizilj 1991, 94 sl.; Griesser Pečar 2005; 2006). Razlike med republikami odražajo že precejšnja odstopanja pri deležu duhovnikov, vključenih v režimu prijazna duhovniška društva. Če jih je bila v Bosni in Hercegovini (pri tem zlasti v Bosni) včlanjena precejšnja in v Sloveniji vsaj v začetku blaga večina (Kolar 2008; Griesser Pečar 2017), je bil delež duhovnikov v stanovskem društvu na Hrvaškem vedno majhen (Akmadža 2013, 131-138). Izjema je bila hrvaška Istra, vendar je imelo društvo tam drugačno izhodišče (Akmadža 2013, 151-161; Ramet 1990, 192).

Tudi sicer je bila dihotomija med Cerkvijo na Hrvaškem (v njeno orbito so nekako spadali še katoličani v Bosni in Hercegovini, v Boki Kotorski in deloma v Bački v Vojvodini, kjer je bila večina katoliške skupnosti sicer madžarsko govoreča) in v drugih delih Jugoslavije, zlasti seveda v Sloveniji, ena potez položaja katoliške skupnosti v Titovi državi, na katero je bilo treba vedno misliti. Pri tem Hrvatje niso tvorili samo hrbtenice vseh katoličanov, marveč je imela Cerkev, kot že omenjeno, vsaj znotraj njihove matične republike boljše izhodišče in boljši institucionalni okvir od tistega v Sloveniji. Po vsem videzu ji je bilo v prid, da pred drugo svetovno vojno 
ni bila močno ali sploh ne navezana na daleč najmočnejšo hrvaško stranko HSS (Hrvatska seljačka stranka) in pravzaprav niti na nobeno drugo stranko ne. Omenjeno za Cerkev v Sloveniji in njen odnos do SLS kajpak ne velja. Seveda je bilo Cerkvi na Hrvaškem mogoče očitati sodelovanje z oblastmi Neodvisne države Hrvaške med drugo svetovno vojno, ki so izvajale katastrofalno politiko do Srbov in Judov, s čimer so precej prispevale k zaostritvi, celo posurovljenju značaja vojaških spopadov v Jugoslaviji in so sploh predstavljale celo med satelitskimi režimi sil osi še posebej ponesrečen eksperiment (Radelić 2012, 39-41; Radić, 2014, 694; Friš, Maver in Maver Šoba 2018, 959-960). Kljub temu so hrvaški katoličani v osebi zagrebškega nadškofa Alojzija Stepinca obdržali močno simbolno in vsaj do procesa leta 1946 tudi vodstveno figuro. Glede njega se zdi, da ga komunističnemu režimu kljub vsemu vloženemu trudu v očeh znatnega dela hrvaške javnosti nikdar ni uspelo v zadostni meri očrniti (Ramet 1990, 184 sl.). ${ }^{2}$ Cerkveni voditelji slovenskih katoličanov, ki so ostali na slovenskem ozemlju, so bili v celoti gledano za oblast manj trd oreh, kar je ta vsaj občasno tudi priznala in jim pripisovala »blažilen vpliv« znotraj jugoslovanskega episkopata (Griesser Pečar 2010, 453-454). Pri njihovih hrvaških kolegih so nasploh ugodnejši pogoji delovanja narekovali odločnejši odnos ne le do komunističnih oblastnikov, temveč tudi do »centrale« Cerkve v času pogajanj o sporazumu s SFRJ (Casaroli 2001, 359-361).

S tem v zvezi bi bilo verjetno treba dodati še nekaj. Iz vseh že nakazanih razlogov se zdi, da je bilo Cerkvi na Hrvaškem lažje ohranjati povezavo, celo kontinuiteto s predvojnim izročilom življenja katoliške skupnosti. V Sloveniji je bilo možnosti za javno delovanje cerkvenih predstavnikov že v osnovi bistveno manj, pa še pri tem je bil do besede pripuščen le del katoliške skupnosti. Krivično bi bilo ob tem najprej pomisliti na največje oportuniste. Kajti ob branju od leta 1971 izhajajoče revije Znamenje postane sorazmerno hitro jasno, da so v prvih vrstah ljudje, ki so bili zaradi svojih stališč (poenostavljeno jim navadno rečemo krščanskosocialistična) v cerkveni srenji iz časa med svetovnima vojnama odrinjeni na rob, in njihovi miselni dediči. Njihova naklonjenost socializmu, socialistični družbi in samoupravljanju vsaj v dobršnem delu ne more veljati zgolj

2 "Uradni« pogled oblasti na Stepinčevo prevladujočo vlogo v zgodnjem povojnem obdobju pa predstavi Roter (1976, 277-279). 
za pozo. Toda še bolj od splošnega očitka oportunizma bi bilo narobe, če bi iz delovanja in pisanja te skupine sklepali na utrip celotne katoliške skupnosti v tedanji Sloveniji; verjetno njihovi pogledi niti večinski niso bili. Dejstvo namreč ostaja, da je bil na javni molk, bodisi zaradi odhoda iz Slovenije bodisi zaradi režimske prisile, obsojen prav tisti del katoličanov, ki je bil pred drugo svetovno vojno nosilec prevladujočih pogledov in teženj. Iz omenjenega razloga je še danes izražano mnenje posameznikov o sedemdesetih letih 20. stoletja kot "zlati dobi« dialoga znotraj Cerkve in z oblastjo sicer nedvomno treba upoštevati. ${ }^{3}$ Toda nesmotrno bi ga bilo kakorkoli posploševati ali celo jemati za suho zlato.

\section{Omejitve in pasti »vzhodne politike»}

Tisti, ki prvo pokoncilsko desetletje v življenju Cerkve na Slovenskem štejejo za obdobje dialoga in včasih celo izgubljenih priložnosti za prihodnost, običajno hvalijo tudi dosežke t. i. »vzhodne politike« Pavla VI. (Grmič 1987). Ta je pomenila predvsem časovno in z okoliščinami pogojen poskus odgovora vodstva svetovne Cerkve na razmere v Srednji in Vzhodni Evropi po koncu druge svetovne vojne. Tudi v zgodovinopisju tako radi izpostavljajo skoraj popolno nasprotje med pristopoma papeža Pija XII., ki naj bi ne bil naklonjen kakršnemukoli sporazumevanju z novimi komunističnimi gospodarji katoliškega evropskega vzhoda, in zlasti njegovega nekdanjega tesnega sodelavca, papeža Pavla VI. (Banac 2013, 113-115). Temelje za spremembe pa naj bi v bistvu postavil že Janez XXIII.

Besedna zveza "vzhodna politika« se v širšem pomenu uporablja že za vatikanska prizadevanja za vzpostavitev vsaj osnovnih pogojev za delovanje Katoliške cerkve v Sovjetski zvezi po prvi svetovni vojni. Tedaj se je pod sovjetsko peto znašlo še razmeroma malo katoličanov, zlasti v zahodnih republikah Belorusiji in Ukrajini (Stehle 1990, 348 sl.). V ožjem smislu se pojem po analogiji z zunanjepolitičnim obratom zahodnonemškega kanclerja Willyja Brandta $\mathrm{v}$ šestdesetih in zgodnjih sedemdesetih letih 20. stoletja (Nećak 2013) skoraj izključno nanaša na zbliževanje med Svetim sedežem in deželami socialističnega bloka. Zanj je bil ob Pavlu VI. 
najzaslužnejši poznejši dolgoletni državni tajnik Agostino Casaroli (Grmič 1987, 98; Casaroli 2001). Vatikan naj bi pri tem s svojim razumevanjem za nekatere želje srednje- in vzhodnoevropskih socialističnih režimov največ dosegel v odnosih z Madžarsko in SFRJ, čeprav je nekaj izboljšav iztržil tudi v Sovjetski zvezi, na Češkoslovaškem in v NDR (Stehle 1990, 351-354).

Jugoslovanski primer v okviru "vzhodne politike« v glavnem velja skoraj za svetilnik (Akmadža 2013, 282-324, 373-379). Upoštevati je tudi treba, da sta večina pogajanj in sklepanje protokola potekala v ozračju velikih pričakovanj med celotno jugoslovansko katoliško skupnostjo. Ta je bila povezana z drugim vatikanskim cerkvenim zborom. Predvsem liturgična reforma in uvedba ljudskih jezikov v katoliško bogoslužje sta naleteli na navdušen sprejem tako v Sloveniji kot na Hrvaškem (Lah 2001, 15; Šanjek 1996, 478-484). Omenjeno vzdušje je potem določalo prepričanje, da je mogoče dejansko izboljšanje položaja vernikov v jugoslovanski družbi.

A tu takoj trčimo ob omejitve "vzhodne politike«. Ne gre samo za številne primere, ko se zdi, da je moral Sveti sedež pristati na domala ponižujoče koncesije. V primeru Kádarjeve Madžarske je vatikanska prilagoditev ob koncu precej nepietetno pometla s pogumnim (sicer pogosto še v avstro-ogrskih kategorijah mislečim) kardinalom Józsefom Mindszentyjem in na površje naplavila oblastnikom precej všečnejšega nadškofa Lászla Lekaija (László, 1990, 169 sl.). Na Češkoslovaškem so se morali recimo sredi najhujše represije po zatrtju praške pomladi v Rimu sprijazniti z imenovanjem režimu popolnoma lojalnega Josefa Vráne za apostolskega administratorja v Olomoucu (Casaroli 2001, 254 sl.; Kolar 2008, 239). Nič drugače ni bilo, kar zadeva dogovarjanje s SFRJ. Celo iz Casarolijevih zapiskov je mogoče razbrati, da pri sklenitvi protokola leta 1966 ni šlo za nikakršen kompromis v ožjem smislu (2001, 358-362). Če kdo, je kaj iztržil Sveti sedež, ko si je zagotovil uradne odnose in nadaljnje vsaj teoretično nemoteno zasedanje položajev v katoliški hierarhiji. To je bila, kot že omenjeno, res velika primerjalna prednost Cerkve v Jugoslaviji. Toda cena je bilo ponižujoče določilo, ki je cerkveno vodstvo tako rekoč zavezovalo k »ovajanju « komunističnim oblastem tistih duhovnikov, ki bi jim bili posebej nenaklonjeni. Grmič (1987) je sicer določilu pripisoval precejšen pomen za izgradnjo domnevno obetavnih odnosov med Cerkvijo in državo, toda zlasti Hrvatom je ponižujoča obveznost povzročila neizmerne bolečine (Casaroli 2001). 
Podrobnejši pogled verjetno neizogibno pokaže, da je šlo za sporazumevanje, ki je bilo povsem v skladu s temeljno usmeritvijo celotne, ne le Pavlove politike do katolištvu načeloma nenaklonjenih režimov. Zelo dobro jo je opisal Hansjakob Stehle (1990, 325-6):

A zakaj Vatikan noče prekiniti dialoga niti s skrajno neprožnimi partnerji? Odgovor se skriva v rimskokatoliškem pogledu, ki ga protestanti ne delijo, da so hierarhične strukture nujne. Brez papeža ne more biti škofov, brez škofov ne duhovnikov, brez duhovnikov ne zakramentov (z izjemo krsta želja ali krvi), brez zakramentov (ki jih morejo veljavno podeliti celo nevredni duhovniki) pa ni zveličanja duš. Ta dogmatična načela iz umestitve škofov in splošnih poroštev za institucije naredijo osrednjo težavo vse vatikanske vzhodne politike. Ker je Katoliška cerkev v svoji samopodobi javna organizacija, in ne skrivni kult, mora imeti zakonske možnosti, da pod slehernim režimom svobodno izvršuje svoje poslanstvo.

Tu smo neposredno soočeni s še hujšimi pastmi in omejitvami uspešnosti vzhodne politike v Jugoslaviji (in sicer), kot so bila prej navedena simbolna ponižanja. Sveti sedež in katoliška hierarhija sta verjetno dosegla nekakšno izboljšanje stanja zase, ki se je v Jugoslaviji poleg prej navedenega odrazilo v na novo zarisanih mejah škofij in predvsem v ureditvi novih cerkvenih pokrajin, med katerimi je bila tudi slovenska (Dolinar 2002, 17-18; Akmadža 2013, 349-357). Po Grmičevem mnenju (1987, 103) je pozitivno vzdušje v meddržavnih odnosih med Vatikanom in SFRJ narekovalo še hitro obnovo samostojne koprske škofije in preureditev meja poreško-puljske škofije po podpisu Osimskih sporazumov.

A z vso silo se zastavlja vprašanje, v kolikšni meri, če sploh, je sporazum olajšal sproščeno versko življenje v socialistični družbi povprečnega jugoslovanskega in v tem okviru slovenskega katoličana. Neproblematično sliko, kot so jo denimo v Znamenju v sedemdesetih letih ponujali nekateri privrženci vzhodne politike Pavla VI., ${ }^{4}$ je težko sprejeti. Res pa se zdi,

4 Dober zgled takega slikanja razmer, ki z današnjega vidika deluje skoraj otročje, je uvodnik »Splošna usmeritev revije v letu 1979«(Znamenje 8: 473), kjer je med drugim rečeno: »Razprava o tem poloŽaju [položaju verskih skupnosti] in o izvajanju zakona o pravnem položaju verskih skupnosti v SR Sloveniji je v skupščini SRS pokazala, da se veren človek resnično lahko včleni kot enakopraven član v samoupravno socialistično družbo in da so primeri zaviranja v tem pogledu vedno bolj redki." 
da bistvene razlike med lastnim optimističnim dojemanjem in nespremenjenim, celo poslabšanim položajem dobršnega dela katoliške skupnosti ni razumel (ali vsaj hotel videti in razumeti) niti škof Grmič (Maver 2013, 613 sl.). Tudi sicer kar malo preseneča razkorak med dejansko razvidnimi sorazmerno sproščenimi odnosi med vrhom vesoljne Cerkve in jugoslovanskim vodstvom, s katerim so ravno tako uspešno sodelovali nekateri jugoslovanski škofje, ter med povečanjem težav v vsakdanjem verskem življenju (Akmadža, 2013 411-430). Kajpak omenjeno ni bilo brez zveze z razvojem odnosov med državo in Cerkvijo ter z nepovezanim obračunom z že omenjenim partijskim »liberalizmom« in hrvaško pomladjo, do katerih je prišlo skoraj sočasno z vrhuncem v odnosih med Titom in Pavlom VI. (Repe 1992; Gabrič 2008; Banac 2013, 125-131).

Nič čudnega ni, da so bili znova hrvaški škofje tisti, ki so jasneje od slovenskih kolegov postavljali tovrstne absurde ob sramotilni steber. Franjo Šeper, Stepinčev naslednik in v tem času že prefekt kongregacije za verski nauk, je na kosilu v dubrovniškem hotelu Argentina s predstavniki oblasti med praznovanjem tisočletnice prenosa relikvij sv. Blaža (Vlaha) v Dubrovnik februarja 1972 izrekel jasne besede, češ da nadaljnji razvoj odnosov med Cerkvijo in državo ne sme ostati na ravni državnih voditeljev in škofov, marveč morajo biti normalni, se pravi svobodni, ravno na najnižji ravni, v bazi (Akmadža 2013, 402). Srčiko njegovega govora je na zasedanju jugoslovanske škofovske konference naslednji dan takratni zagrebški nadškof Franjo Kuharić povzel v krilatico "Tito i papa se rukuju a raja strada" (Akmadža 2013, 403).

Politična oblast je javnosti dejansko vseskozi dopovedovala, da so resnična težava zgolj ambicije nekaterih škofov po politični moči, a je ravno z episkopatom razmeroma lahko dosegla sporazum. Seveda so škofje v Jugoslaviji enako kot drugod po Evropi večinsko menili, da bo prevlada komunizma še dolga. Bolj ali manj jasno je, da sta v enakem duhu delovala drugi vatikanski koncil in administracija papeža Pavla VI.

Optiko slovenskih in jugoslovanskih oblasti, kar zadeva življenje katoliške skupnosti po drugi svetovni vojni, dobro odraža znano razmišljanje tedanjega člana Minikoordinacije za spremljanje dejavnosti Katoliške cerkve v Sloveniji Milana Kučana iz leta 1978. Slednji je na eni od sej omenjenega organa "zastavil osnovno vprašanje, ali lahko politika Cerkve, ki ima 
šibko podlago, ker temelji le na realizaciji v hierarhiji, dobi dovolj podpore tudi med vernimi množicami ali ne« (Bizilj 1991, 14-15). V njegovem spraševanju je prejkone šlo za preslikavo podobe iz imaginarija tedanjih vladajočih struktur, povezano z nekaterimi propagandističnimi poudarki. Slovenski škofje, med katerimi takrat ni bilo izrazite vodstvene osebnosti oziroma je bil najbolj karizmatičen in najagilnejši tedanji član episkopata pod Alpami, Vekoslav Grmič, najbolj naklonjen ne samo sporazumevanju z oblastjo, marveč očitno tudi njenim družbenopolitičnim konceptom (Pacek 2017), so bili še precej bolj obvladljiv in predvidljiv sogovornik od hrvaških kolegov. Zato so lahko bili naslovniki otoplitve odnosov veliko prej kot navaden vernik.

\section{3 »Grmičeva doba in njen zaton}

Hitri vzpon Vekoslava Grmiča v Cerkvi na Slovenskem ob koncu šestdesetih let 20. stoletja in njegov tako rekoč prevladujoči položaj v njej v naslednjih desetih letih sta se dobro prilegala zunanjim in notranjim okoliščinam, ki sem jih doslej opisoval. Mož je s svojo relativno mladostjo, pastoralno zagnanostjo, ki so jo verniki pri njem cenili skoraj vse do njegove smrti, in odprtostjo za sodobne teološke tokove in vprašanja nekako poosebljal evforijo, ki je tudi v vesoljni Cerkvi spremljala koncilsko dogajanje in prva leta po njem (Lah 2001; Pivec 2016). Omenjena evforija je sicer v veliki meri pomenila nadaljevanje že predvojnih prizadevanj številnih slovenskih katoličanov zlasti na liturgičnem področju, toda po drugi strani je postavila pod vprašaj konservativno teološko in cerkvenopolitično usmeritev, ki je v Cerkvi pod Alpami prevladovala pred prelomom druge svetovne vojne. Slednja je bila seveda v razmerah povojne komunistične prevlade odrinjena povsem na rob javnosti skupaj s svojimi nosilci, tistimi, ki so preživeli in ki niso rešitve poiskali v izgnanstvu. Zaradi koncilskih izhodišč, ki so se, kot rečeno, napajali ob misli, da bo sobivanje s sovjetskim političnim mastodontom zelo dolgo, je zdaj tudi teološka misel na svetovni ravni postala nekako prijaznejša vsebinskim izhodiščem socialističnih režimov, čeprav jim seveda prazne menice ni izdajala do te mere, kot je to v zavetju koncilskega dokumenta Gaudium et spes pogosto počel Grmičev krog.

Grmič sam ni nikoli skrival svoje idejne bližine do nekaterih osrednjih vsebinskih postulatov povojnih slovenskih oblastnikov, kar mu je nedvomno 
šteti v prid. To je velikokrat izpovedal. V enem od intervjujev se je v poznih letih spominjal, da je na Ozni že v času službovanja na Vranskem v petdesetih letih 20. stoletja izjavil tole: »Povedal sem jim, da sem po prepričanju socialist. To ne pomeni, da sem zagovornik komunizma, a tudi nasprotnik ne.«(Grandovec 2003, 177) In še tik pred smrtjo je o razmerju med Katoliško cerkvijo in socializmom razmišljal:

Nastal je paradoks, kajti temeljna ideja socializma je sama po sebi globoko krščanska, kot so krščanske ideje tudi ideje francoske revolucije: enakost, svoboda in bratstvo. Krščanska ideja je tako tudi ideja solidarnosti med ljudmi, ki jo je po letu 1945 želel v življenju uresničiti socializem - takratna komunistična oblast. [...] Sedaj v kapitalizmu pa je stvar drugačna. Cerkev nima neke duhovne sorodnosti z idejo kapitalizma, pa čeprav se nekateri tako trudijo in človekove pravice, ki jih formalno zagotavlja kapitalistična družbena ureditev vsakemu posamezniku, revnemu ali bogatemu, jemljejo za dokaz sorodnosti kapitalizma z idejami evangelija. (2005, 139-140)

Seveda se je navdušenje nad socialističnimi zamislimi pri Grmiču napajalo v izkušnji težavnih socialnih razmer v njegovem domačem vzhodnoštajerskem prostoru v obdobju med obema svetovnima vojnama. Slednjo je delil s številnimi bližnjimi rojaki, ki so se prav tako prebili med vodilne oblikovalce katoliške misli na Slovenskem. Temu je treba dodati še v istem prostoru precej zakoreninjeno prepričanje o domala »odrešenjskem pomenu« leta 1918 nastale južnoslovanske državne tvorbe za vzhodnoštajerske Slovence, ki se je kajpak razmahnilo že veliko pred Grmičem. Razvidno je denimo pri zgodovinarju in filozofu Francu Kovačiču, ključni figuri vzpostavljanja slovenske znanstvene infrastrukture v Mariboru. Med njegovimi zapisi ob nastajanju nove države najdemo med drugim tudi take misli:

Pri nas je narodnostno načelo doseglo svoj vrhunec v ujedinjenju in samostalni državi. V smeri enotne državnosti se mora tudi naprej gojiti in razvijati narodna zavest, vsako partikularistično stremljenje mora stopiti v ozadje. Vse eno je, je li kdo Hrvat, Srbin ali Slovenec ali po rodu celo Nemec ali Madžar, da ima le zavest jugoslovanske 
državnosti. V velikem svetovnem metežu je v državnem ujedinjenju spas tudi naše partikularne individualnosti. $(1920,156)$

Zdelo se je torej, da pristajanje na socialistični in obenem jugoslovanski okvir slovenske družbe skupaj s precejšnjim prestižem, ki ga je pomožni škof Grmič užival med verniki kot vidni nosilec pokoncilskih prenovitvenih teženj, za katere se je vsaj spočetka ogrevala večina slovenske katoliške skupnosti, predstavljajo ugodno mešanico, da bi lahko najdejavnejši tedanji slovenski teolog nastopil tudi kot nekakšen prvoborec za izboljšanje položaja slovenskega katoličana. Vsekakor so nekaj takega takoj po njegovem imenovanju za škofa pričakovali celo komunistični oblastniki, saj so v analizi Verske komisije leta 1969 zapisali: „Tako je po drugi strani očitno, da bodo nakazane kvalitete dr. Grmiča kot sodobnega pokoncilskega predstavnika Katoliške cerkve prišle do izraza pri uveljavljanju pravic Cerkve glede vseh vprašanj, ko dr. Grmič smatra, da bi morala Cerkev dobiti več svobode kot doslej. Slovenska Cerkev, predvsem njen mlajši kader, to spoznava. Tudi to je razlog Grmičeve popularnosti.«(Griesser Pečar 2010, 452)

Ugodno Grmičevo izhodišče je doživelo potrditev v njegovem skoraj meteorskem vzponu na vrh cerkvene hierarhije na Slovenskem. Zaporedoma je postal mariborski pomožni škof, predstojnik novovzpostavljene enote ljubljanske Teološke fakultete $\mathrm{v}$ Mariboru in predsednik Mohorjeve družbe. Na teološkem področju mu je uspelo v pokoncilski evforiji izpeljati pomemben projekt prevoda Holandskega katekizma, katerega gonilna sila je bil in h kateremu mu je uspelo pritegniti tudi nekatere izobražence zunaj ozko cerkvenih vrst. Nesporno je tudi, da je nosila slovenska znanstvena teologija v naslednjem desetletju precej njegovega pečata. S svojo izrazito koncilsko usmeritvijo, ki se je sočasno, kot že večkrat nakazano, družila z relativno naklonjenostjo vsebinskim izhodiščem političnih oblasti, je tako Grmič močno utrdil svoj vsaj dejansko izstopajoč položaj na vrhu cerkvene hierarhije. Simbolno se je omenjeno, denimo, pokazalo, ko je leta 1977 prav on napisal uvodno besedo k prevodu in priredbi kompendija dokumentov cerkvenega učiteljstva Heinricha Denzingerja izpod peresa Antona Strleta, ki bi sicer težko veljal za škofovega somišljenika (Maver 2013, 608 sl.).

Kljub vsemu naštetemu se ni uresničilo pričakovanje, da bo Grmič (s svojim krogom) spričo svoje priljubljenosti in energije dosegel tudi 
pomembne premike $\mathrm{v}$ razmerju med Cerkvijo in političnimi oblastmi, predvsem kar zadeva $v$ sedemdesetih letih slabšajoči se položaj povprečnega vernika (Ramšak 2018) in celo naraščajoče težnje po ateizaciji javnega življenja (o čemer se je z obžalovanjem razpisalo celo Znamenje) (Maver in Ravnikar 2017). Kje se je zalomilo?

Ponovno je treba opozoriti na preplet zunanjih in notranjih dejavnikov. Ključni zunanji dejavnik je bil enak tistemu, ki je privedel do precej sladkokislih sadov Pavlove »vzhodne politike«, kot mora med vrsticami pogosto priznati celo njen arhitekt Casaroli (2001). Popolna iluzija je namreč bila, da je mogoča kakršnakoli oblika enakovrednega dialoga s komunističnimi oblastmi v Srednji in Vzhodni Evropi. Dokler so bile te pri moči, jim je sklepanje dogovorov s Cerkvijo služilo le kot nekakšen figov list, pri čemer kajpak niso nameravale odstopati od temeljnih postulatov svoje verske politike. Drugače je bilo le ob koncu osemdesetih let 20. stoletja, ko se je njihov položaj razrahljal, ali pa v okoljih, kjer je Katoliška cerkev razpolagala z izjemno močno podporo pri ljudeh, kar je v obravnavanem obdobju veljalo praktično samo za Poljsko in še za nekatere otoke, kakršen je bil vzhodnonemški Eichsfeld, v Jugoslaviji nemara deloma Hrvaška. Pri tem ni ničesar spremenilo dejstvo, da se je Cerkev v pokoncilskem obdobju (tudi pod vplivom leta 1968 na Zahodu) v odnosu do socializma in nekaterih drugih - vsaj papirnatih - postavk vzhodnoevropskega komunizma verjetno znatno omehčala.

Da šteje njihova idejna bližina oblastnikom le malo in da so zanje še vedno predvsem predstavniki konkurenčne ali bolje kar sovražne organizacije, niso dobro razumeli niti v Grmičevem štajerskem krogu. S tem so se podobno kot številni eksponenti »vzhodne politike« znašli v nehvaležnem položaju (neprostovoljnih?) sopotnikov režima, ki za zaupano jim čredo dolgoročno ni predvidel samostojnega prostora. Toda še bolj je priljubljenost njihovih pogledov, ki so vsaj sprva dobro zadeli struno pokoncilskega razpoloženja, znižala zaostritev nekaterih nikakor ne večinskih stališč znotraj katoliške skupnosti domala do skrajnosti.

Še enkrat naj poudarim, da je »vzhodnoštajerski tok«v slovenskem katolištvu s svojim poudarjanjem socialne problematike, zagovarjanjem »deklerikaliziranega krščanstva« in poudarjanjem elementov ločitve Cerkve od države vsekakor spregovoril o dejanskih problemih pomembnega dela 
slovenskih katoličanov. Da je bil v predvojni katoliški skupnosti potisnjen precej na rob, je prispevalo k razkolu v njej. Da so njegovi zagovorniki v spremenjenih razmerah po drugi svetovni vojni začutili priložnost za vidnejšo uveljavitev, je razumljivo.

A Grmičev krog je prignal skoraj vsako postavko svojih idejnih predhodnikov, ki jim lahko jasno sledimo na črti Kovačič-Janžekovič-Kocbek, do absurda. Stopnjeval je čezmerno poudarjanje prepada med izkušnjo lavantinske in ljubljanske krajevne Cerkve v 19. in 20. stoletju in pri tem praviloma spregledoval, da je povojna komunistična oblast sicer priznavala drugačno medvojno usodo Cerkve na Štajerskem, da pa to v vsakdanjem življenju vernikov in duhovnikov ni imelo nobenih posledic (Griesser Pečar 2010, 437-438). Podobno je še prekosil predhodnike v izigravanju razmerja med narodno in versko pripadnostjo, pri čemer mu je poudarjanje prednosti narodnosti služilo tudi kot dobrodošlo orodje za apologijo socialističnega družbenega modela, porojenega iz revolucije. S tem si je tako rekoč žagal vejo, na kateri je sedel, saj je spodkopaval skoraj vsako možnost za oblikovanje katoliških kulturnih konceptov, ki bi vsaj v čem bistvenem odstopali od tistih Cerkvi nenaklonjenih oblasti (Maver in Ravnikar 2017). Omenjeno lepo kaže zapis Jožeta Rajhmana s konca sedemdesetih let, kjer je podrejenost verske pripadnosti narodni izrazito podčrtana:

Nam (katoličanom) je narod prvo. Najprej moramo živeti, potem moremo živeti krščansko. [...] Mislim, da je ta pot bila potrebna, da bi videli, [...] da je razvoj znotraj krščanstva samega, posebej seveda v pokoncilski dobi, pokazal nevzdržnosti nekdanjih »katoliških" stališč v slovenskem katolicizmu, posebno ko je koncil spregovoril o avtonomiji zemeljskih danosti, med katere po splošnem mnenju spadata tudi pojma narod in narodnost. Zavedati pa bi se morali, da je slovenska Cerkev v svoji zgodovini ta pojma preveč »izkoriščala" v svoje stranske namene, da sta se ta pojma že zdavnaj izkristalizirala zunaj Cerkve kot samostojna enota, da se ne bomo več mogli z njima "poigravati«, temveč bomo ob vedno znova resnični »historia docet« znali iskati zase svoj prostor v slovenskem narodu. (Rajhman 1979, 405-406) 
Iz podobnih koncilskih izhodišč je vodilni pred- in pokoncilski teolog na Hrvaškem Tomislav Šagi Bunić lahko (resda hkrati v drugačnih okoliščinah) prišel do bistveno drugačnih sklepov (Banac 2013, 226-237). Končno je kajpak treba omeniti, da je k upadu vpliva Vekoslava Grmiča v Cerkvi na Slovenskem prispevalo spremenjeno ozračje na vrhu Cerkve po izvolitvi izrazitega protikomunista Janeza Pavla II. na Petrov sedež, toda ta dejavnik ni bil tako močan, kot so domnevali in domnevajo nekateri zagovorniki Grmičeve poti (Kovačič Peršin 2012). Menim, da je šlo predvsem za posledico vedno večjega razkoraka med škofovim lastnim dojemanjem uspešnosti dialoškega odnosa z oblastjo in občutenjem večine slovenske katoliške skupnosti.

\section{Reference}

Akmadža, Miroslav. 2013. Katolička Crkva u komunističkoj Hrvatskoj 1945-1980. Zagreb: Despot Infinitus.

Altermatt, Urs. 2007. Katholizismus und Nation. Vier Modelle in europäisch-vergleichender Perspektive. V: U. Altermatt in F. Metzger, ur. Religion und Nation. Katholizismus im Europa des 19. und 20. Jahrhunderts, 15-33. Stuttgart: Kohlhammer.

Ambrožič, Matjaž. 2011. Politična dejavnost knezoškofa Jegliča v očeh sodobnikov. Studia Historica Slovenica 11: 585-611.

Bajc, Gorazd. 2014. Dietro le quinte della visita di Tito a Roma nel 1971: il contesto locale e internazionale letto dalla diplomazia britannica. Annales, Series Historia et Sociologia 24: 713-732.

Banac, Ivo. 2013. Hrvati i Crkva. Kratka povijest hrvatskog katoličanstva u modernosti. Zagreb: Profil.

Bizilj, Ljerka. 1991. Cerkev v policijskih arhivih. Ljubljana: samozaložba.

Casaroli, Agostino. 2001. Mučeništvo strpljivosti. Sveta stolica i komunističke zemlje (1963-1989). Zagreb: Kršćanska sadašnjost.
Čipić Rehar, Marija. 2007. Odnos Mihaela Toroša do CMD. V: E. Škulj, ur. Torošev simpozij v Rimu, 227-238. Celje: Celjska Mohorjeva družba.

Dolinar, France Martin. 2002. Cerkvenoupravna podoba Slovenije. V: M. Benedik, J. Juhant in B. Kolar, ur. Cerkev na Slovenskem v 20. stoletju, 7-24. Ljubljana: Družina.

Dolinar, France Martin. 2006. Die Kirche in Slowenien. 1961-1990. V: J. Mikrut, ur. Die katholische Kirche in Mitteleuropa nach 1945 bis zur Gegenwart. Dunaj: Dom.

Dolinar, France Martin. 2007. Die Position der katholischen Kirche unter den Slowenen 1848-1937 unter besonderer Berücksichtigung der Region Krain. V: W. Drobesch, R. Stauber in P. G. Tropper, ur. Mensch, Staat und Kirche zwischen Alpen und Adria 1848-1938. Einblicke in Religion, Politik, Kultur und Wirtschaft einer Übergangsze , 239-245. Celovec, Ljubljana, Dunaj: Hermagoras/Mohorjeva družba. 
Friš, Darko, Aleš Maver in Nataša Maver Šoba. Arheologija vic in pekla. K tipologiji koncev druge svetovne vojne v Evropi. Acta Histriae 26: 945-972.

Gabrič, Aleš. 2008. "Maspok« in Slovenci. Studia Historica Slovenica 8: 457-476.

Goeckel, R. F. 1990. The Catholic Church in East Germany. V: P. Ramet, ur. Catholicism and Politics in Communist Societies, 93-116. Durham, London: Duke University Press.

Grandovec, Helena. Zgodbe iz življenja. V: I. Arzenšek, ur. Zbornik ob 80-letnici škofa Grmiča, 172-186. Petrovče: Znamenje.

Griesser Pečar, Tamara. 2002. Duhovščina med nacizmom, fašizmom in komunizmom. V: M. Benedik, J. Juhant in B. Kolar, ur. Cerkev na Slovenskem v 20. stoletju, 285-298. Ljubljana: Družina.

Griesser Pečar, Tamara. 2005. Cerkev na zatožni klopi. Sodni procesi, administrativne kazni, posegi "ljudske oblasti « v Sloveniji od 1943 do 1960. Ljubljana, Družina.

- - -. 2010. Lavantinska škofija v novi Jugoslaviji. Studia Historica Slovenica 10: 429-462.

- - -. 2016. Katoliška cerkev na Slovenskem leta 1945. Studia Historica Slovenica 16: 399-418.

- - -. 2017. Cirilmetodijsko društvo katoliških duhovnikov LRS in »judska oblast « med najhujšo represijo. Bogoslouni vestnik 77: 423-437.

Grmič, Vekoslav. 1987. Dvajset let po podpisu protokola med SFRJ in Vatikanom. Prešernov koledar 1988: 98-105.

- - -. 2005. Poslednji spisi. Misli o sodobnosti. Ljubljana: Unigraf.

Kerševan, Marko. 1989. Religija in slovenska kultura. Ljudska religioznost, civilna religija in ateizem $v$ Sloveniji. Ljubljana: Partizanska knjiga.

Kolar, Bogdan. 2008. The priestly patriotic associations in the Eastern European countries. Bogoslovni vestnik 68: 231-256.

- - -. 2014. Cerkveno dogajanje v Ljubljani med svetovnima vojnama. Studia Historica Slovenica 14: 357-377.
- - -. 2018. Odpravnik poslov mons. Silvio Oddi in katoliška Cerkev v Sloveniji. Bogoslovni vestnik 78: 557-590.

Košir, Borut. 2002. Cerkev in njen odnos do političnih ureditev. M. Benedik, J. Juhant in B. Kolar, ur. Cerkev na Slovenskem v 20. stoletju, 255-270. Ljubljana: Družina.

Kovačič, Franc. 1920. Narodnostno načelo in mirovna konferenca. Čas 14: 137-157.

Kovačič Peršin, Peter. 2012. Duh inkvizicije. Slovenski katolicizem med restavracijo in prenovo. Ljubljana: Društvo 2000.

Lah, Avguštin. 2001. Sprejem 2. vatikanskega koncila v Sloveniji. V: P. Kvaternik, ur. $V$ prelomnih časih. Rezultati mednarodne raziskave Aufbruch (1995-2000). Cerkev na Slovenskem v času komunizma in po njem (1945-2000), 9-31. Ljubljana: Družina.

László, Leslie. 1990. The Catholic Church in Hungary. V: P. Ramet, ur. Catholicism and Politics in Communist Societies, 156-180. Durham, London: Duke University Press.

Lodrant, Jože. 1979. De omnibus rebus et de quibusdam aliis. Znamenje 9: 386-388.

Lučić, Ivica. 2012. Komunistička represija nad Hrvatima u Hercegovini. V: Represija i zločini komunističkog režima u Hrvatskoj. Zbornik radova, 289-327. Zagreb: Matica hrvatska.

Malmenvall, Simon. 2014. Florentinski koncil (1438-1439). Uspehi in neuspehi v reševanju uniatskega vprašanja. Bogoslovni vestnik 74: 385-397.

- - -. 2016. Razvoj cerkvene organizacije v Kijevski Rusiji do sredine 12. stoletja. Bogoslouni vestnik 76: 547-558.

Maver, Aleš. 2013. Paradoks Vekoslava Grmiča. Studia Historica Slovenica 13: 603-619.

- - -. 2014a. Die Rolle des Klerus im nationalen Emanzipationsprozess der Slowenen. V: A. Jakir in M. Trogrlić, ur. Klerus und Nation in Südosteuropa vom 19. bis zum 21. Jahrhundert, 49-58. Frankfurt am Main: Peter Lang. https://doi.org/10.3726/978-3-653-04006-7/11

- - -. 2014b. V (ne)znanem novem svetu. Paberki iz verskega življenja v Celju 
med svetovnima vojnama. Studia Historica Slovenica 14: 505-518.

- - - in Darko Friš. 2018. Iudica me, Deus. Duhovniki v politiki na Slovenskem ter v srednji Evropi v prvi polovici 20. stoletja in Anton Korošec. Acta Histriae 26: 109-126.

-- - - in Anton Ravnikar. 2017. Zastrta znamenja. Vprašanje disidentstva Katoliške cerkve v Sloveniji v obdobju „vzhodne politike« in revija Znamenje. Annales, Series Historia et Sociologia 27: 793-806.

Nadrah, Ignacij. 2010. Spomini in semeniška kronika 1941-1944. M. Ambrožič, izd. Ljubljana: Arhivsko društvo Slovenije.

Nećak, Dušan. 2013. »Ostpolitik« Willyja Brandta in Jugoslavija (1963-1969). Ljubljana: Znanstvena založba Filozofske fakultete.

Pacek, Dejan. 2016. Nekateri bistveni vidiki odnosa med Svetim sedežem in Jugoslavijo v obdobju 1953-1970. V: B. Kolar, ur. Miscellanea (Acta Ecclesiastica Sloveniae, 38), 361-383. Ljubljana: Teološka fakulteta.

- - -. 2017. Okoliščine imenovanja dr. Franca Krambergerja za mariborsko-lavantinskega škofa ordinarija. Bogoslovni vestnik 77: 53-65.

Pirc, Jožko. 1997. Cerkveni in duhovni tokovi. V: P. Vodopivec in J. Mahnič, ur. Slovenska trideseta leta. Simpozij 1995. Ljubljana: Slovenska matica. 118-138.

Pivec, Franci. 2016. Vekoslav Grmič za življenje brey strahu. Casopis za zgodovino in narodopisje 87 = 52/4: 85-95.

Radelić, Zdenko. 2012. Rat, država, nacija i revolucija: bitne pretpostavke komunističke represije u Hrvatskoj. Represija i zločini komunističkog režima u Hrvatskoj. Zbornik radova, 21-49. Zagreb: Matica hrvatska.

Radić, Radmila. 2014. Jugoslavija i Vatikan 1918-1992. godine. Annales, Series Historia et Sociologia 24: 691-702.

Rajhman, Jože. 1979. Slovenski »Nacionalizem in krščanstvo«. Znamenje 9: 399-409.

Ramet, Pedro. 1990. The Catholic Church in Yugoslavia, 1945-1989. V: P. Ramet, ur.
Catholicism and Politics in Communist Societies, 179-206. Durham, London: Duke University Press.

Ramšak, Jure. 2018. Položaj vernih učiteljev v socialistični šoli v sedemdesetih letih. Šolska kronika 27 = 51: 77-92.

Reban, Milan J. 1990. The Catholic Church in Czechoslovakia. V: P. Ramet, ur. Catholicism and Politics in Communist Societies, 142-155. Durham, London: Duke University Press.

Repe, Božo. 1992. »Liberalizem« v Sloveniji. Ljubljana: RO ZZB NOV.

Rosa, Jurij. 2003. Alojz Kocjančič v Cirilmetodijskem društvu katoliških duhovnikov in v Slovenskem duhovniškem društvu. V: A. Obid, G. Bajc in B. Klabjan, ur. Življenje in delo Alojza Kocjančiča, slovenskega istrskega pesnika, pisatelja in duhovnika. Prispevki s Posveta Slovenski istrski pesnik, pisatelj in duhovnik Alojz Kocjančič, Izola, 18. novembra 2002, 85-100. Koper: Univerza na Primorskem, Znanstveno raziskovalno središče, Zgodovinsko društvo za južno Primorsko.

Roter, Zdenko. 1976. Katoliška cerkev in država v Jugoslaviji 1945-1973. Sociološki teoretični modeli in raziskovalni model. Ljubljana: Cankarjeva založba.

Solchanyk, Roman, Ivan Hvat. 1990. The Catholic Church in the Soviet Union. V: P. Ramet, ur. Catholicism and Politics in Communist Societies, 49-92. Durham, London: Duke University Press.

Stehle, Hansjörg. 1990. Papal Eastern Diplomacy and the Vatican Apparatus. V: P. Ramet, ur. Catholicism and Politics in Communist Societies, 343-355. Durham, London: Duke University Press.

Šanjek, Franjo. 1996. Kršćanstvo na hrvatskom prostoru. Pregled religiozne povijesti Hrvata (7.-20. st.). Zagreb: Kršćanska sadašnjost.

Vogrin, Marjan. 2006. Uresničitev dolgoletnih želja - samostojna škofija. V: B. Klabjan in G. Bajc, ur. Osimska meja. Jugoslovansko-italijanska pogajanja in razmejitev leta 1975, 265-271. Koper: Založba Annales. 